\title{
Is the Professionalisation of Adult Basic Skills Practice Possible, Desirable or Inevitable?
}

\author{
CAROL DENNIS
}

\begin{abstract}
This paper explores the meaning and implications of a policy-driven professionalisation of adult basic skills practice. Written amidst competing theoretical conceptualisations of professionalism, the paper focuses on a particular policy moment in Adult Language, Literacy and Numeracy (ALLN) practice in England: Skills for Life. The paper argues that the possibility of implementation of this policy is limited. The policy is filtered through the fragmented nature of the field, the embeddedness of literacy and what this paper calls an 'anti-professional' stance of ALLN practice. For policy makers, professionalisation is desirable, and its impact is far-reaching. It enables control of a key aspect of the service sector implicated in the supply of flexi-workers required by a globalised economy. In discussing the inevitability of professionalisation the paper draws on a small-scale research project to locate a space for the professional imagination, a space in which ALLN practitioners express motivations at odds with policy imperatives and enact professionalisation in ways that arguably hijack the momentum and resource that the policy provides.
\end{abstract}

\section{Introduction}

In this paper I interrogate the possibility, desirability and inevitability of professionalising adult basic skills practice.

The discussion is written amidst an almost meteoric rise in the last 30 years of theoretical conceptualisations of what it means to be a professional (Harper and Jephcote 2010, Shore and Zannettino 2002). The temporary settlement of classical sociology, which defined professionalism in terms of fixed traits and social functions, has given way to critical onslaught. In contemporary discourse, professionalism is in a state of crisis (Elliott 1996, Robson 1998, Frost 2001, Gleeson and James 2007), a crisis precipitated by a particular policy climate in which issues of trust, authority, moral integrity and expertise - once embodied by the professional - have become disaggregated (Morley 2003:5) or dissolved (Sardar 2000).

In this shifting and diverse terrain, I frame the professional as 'an uncertain being with disparate allegiances', but more significantly as an 'implementer of government policy' (Stronach 2002:109). In doing so I explore a particular moment in the development of adult basic skills - or to 
use its more contemporary name - Adult Language, Literacy and Numeracy (ALLN) in England when what had been a loosely bound and informal occupational space was shunted towards a controlled, defined and closely monitored profession.

I focus on ALLN - with an emphasis on adult literacy. But the discussion is situated within and reverberates across other territories. ALLN is part of the UK's Learning and Skills Sector - LSS - and so included in the policy wave that has engulfed this area. The experience of LSS connects to other occupational groups, health, welfare and schooling, which have all been reconfigured in similar policy driven ways (Clarke and Newman 2005). The UK experience connects to trends across the English speaking centres of economic power which have all, with divergent formulations, translations and transformations responded to the 'globalisation of risk' with a form of policy hyperactivity (Edwards and Usher 2008).

\section{Skills for Life}

In 2000 the UK government, New Labour, developed Skills for Life, a policy that connected poor levels of language, literacy and numeracy achievement among adults living in England to the absence of a "coherent and consistent set of national standards to guarantee the quality of what was being taught [to adults attending basic skills classes], how it was taught and the qualifications [...] awarded to learners' (DfEE 1999:para 1.9). The Skills for Life strategy (DfEE 1999) included:

- Greater participation in ALLN

- Nationally defined core-curricular documents

- Subject specialisms of Adult Literacy, Adult Numeracy and English for Speakers of other Languages

- Teaching and learning materials to accompany the core-curricular documents

- Qualifications for teachers

- Qualifications for learners

- Instituted and devolved national targets for learners' qualifications

- A ring-fenced 40\% funding uplift making ALLN a lucrative curricular proposition

- A new and formalised approach to recording learners' progress

- The establishment of an evidence base to inform practice

It is difficult to overestimate the impact these changes have had. What appears as a neat list is actually a pervasive infrastructure requiring a great deal of local activity. This is what I frame as a policy driven attempt to professionalise ALLN practice. It is worth pointing out that, in this shifting and diverse theorisation, processes I here associate with professionalisation 
have elsewhere been characterised as deprofessionalisation (Randle and Brady 1997) or alternatively reprofessionalisation (Avis, Bathmaker and Parsons 2002) as well as a simultaneous process of both deprofessionalisation and reprofessionalisation (Shain 1999). I have also favoured the term professionalisation - a verb and therefore something active (Harper and Jephcote 2010:5) to place greater emphasis on a fluid, orchestrated process of negotiation and change. Other social theorists have more often used the term professionalism - a noun and by implication something that is or may become static.

The paper draws on theoretical and empirical work to explore the professionalisation of ALLN. In the final section I incorporate interview data of a small scale research project 'Controlling the Imagination' conducted over two years between 2007 and 2009 into the different meanings embedded in the notion of quality when applied to ALLN. While professionalisation was not the focus for this study, what it meant to implement Skills for Life was an ever present concern. The data therefore allows a glimpse of a key aspect of professionalisation.

\section{The professionalisation of ALLN: is it possible?}

In exploring the possibility of professionalisation, I explore the disparate nature of the occupational field that falls within the boundary of ALLN. It is the porous fluctuating nature of ALLN provision that conspires against the idea of ALLN practice as professionalised. I then explore strands within ALLN work that are distinctly anti-professional. By invoking antiprofessionalism, it is not my intention to draw on 'discourses of derision' (Ball 1990) or argue that professionalism amounts to a 'conspiracy against the laity'. I rather suggest that the hallmarks of ALLN practice are antithetical to the distancing and privilege associated with professionalism, shards of meaning that echo its classical conceptualisation.

\section{Literacy and Context}

In defining and defending a moral purpose for adult education, Wilson (2001) equates its inability to attain professional status to the nature of the field. The LSS in the UK is vast. It incorporates all post-compulsory education provision: general further education (FE) colleges, sixth forms (when these are not part of a school), work based learning, community and voluntary organisations, prisons, local authority funded adult education as well as private training organisations. In $2009 \mathrm{FE}$ colleges employed 260,000 staff in various teaching related roles. There are some 20,000 ALLN teachers, an estimated $50 \%$ of whom are employed on a part-time basis (LLUK 2010). As part-time staff they typically exist on the 'slippery edges' (Jameson and Hillier 2008) of organisations. Often working in isolated peripheral centres, they are a 'casualised' workforce who work in conditions 
that make it difficult for them to form and maintain close working contacts with colleagues and managers. In these diverse contexts practitioners, teachers, lecturers, tutors, assessors, section leaders or advanced practitioners (the associated nomenclature indicates the porous nature of the role) out of necessity, develop localised ways of working.

Professionalisation is strongly determined by local learning culture (James and Biesta 2007). What it means to be a professional does not easily translate from one context to another. Working with a group of homeless adults in a large city may require a very different approach to working with primary school parents attending a family literacy class, which may be very different to offering study skills support for students working towards a National Vocational Qualification (NVQ) in construction. Policy may define good practice, but its implementation requires quite considerable degrees of reworking (Coffield and Edward 2009). Practice is constantly recrafted and recreated to suit the changing context. It is this process of engagement, the enactment of policy and professionalisation that creates its multiple but fractal possibilities. Practitioners out of necessity adopt a dynamic approach to teaching literacy in response to learners lives (Castleton 2001). The depth of activity required is echoed in several studies of localised literacy practice (Crowther, Hamilton and Tett 2001), and the work of the National Research and Development Centre (Ivanic et al 2006) enlivens the decisive importance that context plays in this renegotiation. It is possible that this idea of context, and the extent to which it shapes practice, is a re-articulation of the mutually constitutive nature of the world as constructed by the individual, and the individual as shaped by the world. It implies a discussion about the relationship between policy - structure and professionalisation - agency. To emphasise the locality of learning, and the occupational requirements that facilitate it, Haggis (2009:58) offers a version of socio-cultural theories of learning that position cognition as 'far more situated than theories of situated learning imply'.

This fragmentation does not preclude the possibility of any sense of common ground. Skills for Life is after all monolithic policy. Its defining features, targets, qualification curriculum documents, inspection, while mediated by a local context, echo in each place they appear. A part-time practitioner may work in several different main and peripheral centres at any one time. There is fluidity and movement within and between the sectors. Practitioners coalesce around these common themes in how they experience the new infrastructure (Coffield et al 2008). However, even when practitioners travel from one centre to another, the ways in which they perform their role changes considerably to suit their context. Prescriptions of what counts as appropriate practice precludes the possibility of enactment of 
any monolithic policy. The one-size-fits-all policy provides a backdrop, but practitioners - reshape their stance as required. As practitioners move between the centres in the peripheries and the main centre, key relationships between students, and between teaching and non-teaching colleagues assume an unexpected fluidity (Crossan and Gallacher 2009).

In part (though not wholly) this connects to a longstanding and abiding discussion within ALLN practice - namely the distinction made between literacy as skills and literacy as social practice, in as much as a social practices approach to literacy insists on the primacy of context as implicit in what it means to be literate. Once these different conceptualisations of literacy are connected to professionalisation they bring into sharp relief strands within ALLN practice that are distinctly anti-professional.

\section{Anti-professionalism}

I link these anti-professionalisation discourses to the influential work of Freire (1970) who emphasised teaching as part of a process of 'conscientisation': critical thinking that linked pedagogy to developing a wider understanding of the conditions in which adult literacy learners find themselves. Freire advocated a situated approach to understanding literacy, an approach at odds with the autonomous model of literacy that pervades policy constructions but one that has been elaborated upon by the New Literacy Studies (Barton 2007b, 2007a, Crowther et al 2001). According to Freire authentic literacy is not limited to simply getting what the text says, but entwines reading the word and the world. Illiteracy is best understood as an injustice rather than a personal failure. Teaching literacy is an inherently political activity that involves dialogue, mutuality and exchange. Literacy can only be understood when it is placed in a context. It is relational and thoroughly embedded in social and communicative practices. The interest of New Literacy Studies is therefore on literacies rather than a single literacy, to reflect the different literacy practices of an individual negotiating situtations in different contexts, and the different literacy practices that are used to negotiate similar situations by different cultural and social groups.

I describe the Freirean discourses as anti-professional because they are at odds with the professionalisation inscribed in Skills for Life. From a literacies perspective the literacy learners' preferred approaches to managing the various texts that are part of their lives emerge from the particularity of the situation in which they are placed: their context of use. Literacy teaching, to be effective, has to be responsive (Barton 2007b). Literacy learning is here constructed as a rhizome. It precludes the imposition of hierarchies, structures and uniformity and consists of entanglements and contingent dis /connections. This is somewhat at odds with the rigid hierarchical construction of literacy inscribed in the professionalisation of ALLN practice. 
Tusting (2009) explores a further aspect of the professionalising process - notably the extent to which it generates increasingly burdensome amounts of paperwork. Amidst the flurry she notes teachers engaging in a discourse of what it means to do their job well as including the construction of particular types of teacher-student relationships. These include placing value on mutual respect and minimising hierarchy. Crossan and Gallecher (2009) develop further this idea of 'learning relationship' as key to understanding the stance adopted by practitioners based in community learning centres. They deploy concepts of emotion work, underground working and habitus to enliven an understanding of those relationships. They stress the importance of informal, relaxed and friendly pedagogic encounters. The stance that is highly regarded here is one of equality and horizontality. These commitments bear close resemblance to approaches that may be found in contemporary liberatory or Freirean-inspired literacy pedagogy (Jacobson 2009).

What I describe then as anti-professionalisation is a refusal of the distancing and privilege that attends the idea of achieving the professional status partly inscribed by Skills for Life, and partly found in the semiotic lingering of earlier classical associations: the idea of professionals as a high status, special occupational group. To be a literacy tutor is to adopt an antiprofessional stance compelled by a desire to make connections with the learners and their particular contexts.

The possibilities of the professionalising process are limited. The bullet-point lists do not enter a blank slate of ALLN practice, and practitioners do not merely absorb and react with robotic obedience (Ball 1993:12) to their determinations. They read, interpret, mediate and translate (Coffield et al 2008). They then form an opinion and work out what and how to do. The required policy is one of the resources they draw upon to achieve this. Within the professionalisation process there is always much more going on and much less going on than policy makers imagine (Kelchtermans 2007).

\section{The professionalisation of ALLN: is it desirable?}

In exploring the desirability of professionalisation, I ask whose interests does it serve? I have so far framed the process as policy rather than practitioner driven. I am mindful here that it is not always possible to separate policy makers and practitioners since a single individual may occupy several different spaces (Wickert 2001). Nor should describing professionalisation as policy driven be taken to mean practitioners are not interested in improving practice (Hamilton and Hillier 2006). What I suggest here is the following. While social theorists have tended to associate professionalisation as connected to the agitations of practitioners to secure a more prestigious and rewarding place in an occupational market place, the shift of ALLN practice 
from what was a campaign to a national strategy has, in its tone and texture, emerged from a space that is at some distance from practitioners and learners.

\section{Manufacturing flexi-workers}

Within an environment where 'risk has been globalised' (Morley 2003) professionalisation represents the possibility of control amidst the inevitability of chaos. It is the antithesis of all that is multivocal, heterogeneous and unpredictable. Here enshrined in policy is the belief that the literacy a professionalised ALLN practitioner delivers - the literacy inscribed in Skills for Life - is the silver-bullet that pierces the heart of economic decline. The capacity to read and to write in a prescribed way is imbued with super-hero like qualities.

The status of literacy skills as super-hero is a leitmotif that has dominated educational policy discourse re-represented here:

In the 21st Century, our natural resource is our people - and their potential is both untapped and vast. Skills will unlock that potential. The prize for our country will be enormous - higher productivity, the creation of wealth and social justice. The alternative? Without increased skills, we would condemn ourselves to a lingering decline in competitiveness, diminishing economic growth and a bleaker future for all (Leitch, 2006:1).

This faith in the power of skills was translated into a series of targets for qualifications.

95 per cent of adults to achieve the basic skills of functional literacy and numeracy, an increase from levels of 85 per cent literacy and 79 per cent numeracy in 2005 (Leitch, 2006:3).

Several interweaving strands of argumentation define the technical, cultural, political and economic changes that characterise globalisation. The internationalisation of production, restructuring of the labour market, the hyper-fluidity of capital and the need for flexible workers are some of its pick and mix features (Morley 2003). In this environment, education and training have become direct objects of, rather than adjuncts to, economic policy. What a globalised economy creates - according to some theorists - is a reduction in state power and an enhancement in the market. Policy attention shifted towards education in the 1980s onwards largely because with power residing in international corporations, it had nowhere else to go (Hodgson and Spours 1999:5).

The increased focus on skills amounts to an increased focus on creating conditions that make the UK an attractive investment proposition for international corporations. The new economy requires flexi-workers: workers imbued with desirable behaviours and attitudes. While skills have 
for a long time been valued by policy makers as the backbone of industry, their invested meanings have expanded exponentially (Payne 2000). My suggestion here is that the professionalisation of ALLN is a policy driven attempt to monitor and control a section of the service economy, which is key to the production of the kind of workers required in the new globalised work order. Professionalisation creates the mechanisms through which the literacy practices and citizenship status of sections of the population are marginalised, consecrated or stigmatised (Albright and Luke 2008).

This implicates the ALLN practitioner in the creation of the flexiworker who is able to not only survive, but also thrive within the conditions created by a volatile international market place. The flexi-worker is willing to adapt their lives to accommodate the needs of the corporation; is willing to develop the personal skills and dispositions that enable them to cope with the insecurity of un / under (or over) employment. They are controllable and complicit in their own exploitation by being infused (enthused) with the ideals of the corporation (Peters and Austin 1985). Devoid of political ideals they are prepared to accept a redefined welfare state as springboard rather than safety net (Edwards 2003) and become responsible citizens i.e. literate learning citizens. They are positioned by the policy as one being in a perpetual state of deficit, a deficit healed when they are willing to l/earn. Professionalisation implicates ALLN practitioners in this recreation of learner subjectivities (Hamilton 2009).

\section{Ubiquitous management}

Professionalisation also creates anxieties in the micro world of practitioners (Morley 2003:6). It enables the policy maker to tell practitioners who their learners are (Dennis 2009:58), how they are envisioned, that is brought into the public gaze (client, customer, student or learner), and how their learning is valued and described. Through performance monitoring performativity - new ways of steering / directing are created and the structure and culture of public services are recast. The processes here characterised as professionalisation, ensure that ALLN tutors are subject to judgements, classifications, and targets against which they are evaluated.

Performativity defines the value of literacy and numeracy teaching as contained within that which can be recorded and quantitatively measured. Literacy, literacy learning and literacy learners are reduced to a series of observable tasks, activities and outcomes. That which cannot be measured or which does not contribute directly to performativity is without value.

This philosophy filters through the everyday experiences and the social relations between tutors and students. In delivering the literacy inscribed in Skills for Life, the aim is to ensure that students are able to work towards 
individually defined learning goals that are an expression of their personal aims, aspirations and interests. At the same time they have to comply with pre-defined outcomes listed in a core-curriculum. This is a conundrum of biblical proportions: how do practitioners reconcile free choice with predetermination? The two only become reconcilable through translation and betrayal. Students define goals and use a language that does not fit the learning outcomes that professionals are required to deliver - I want to feel more confident, I want to improve. These legitimate goals are not acceptable. They are difficult to record, monitor, list as performance indicators, and prove as achieved. The practitioner is required to change these expressions and the goals themselves and the language they are described in - to meet what has been set out in core-curriculum documents, inspected though the common inspection framework and defined as quality. Management is thus ubiquitous and indivisible, inescapably embedded in everything we do. The learning relationship and with it the trust between practitioner and learner is interrupted. The intrinsic value of education - the notion of literacy learning as anything other than an economic imperative, the idea of literacy as a human right, is outside the discursive framework. There is within this context a displacement of anything that approaches a metaphysical discourse principles of social justice and equity are made irrelevant or at least are only viewed through the prism of economic imperative; fables of hope, promise and opportunity are no longer part of the geography of ALLN.

There are then several possible answers to the desirability of professionalising ALLN. To answer yes, it is desirable, is to adopt the perspective of a government subject to the imperatives of globalisation, struggling to re-orientate policy to ensure it is able to create conditions that promote economic competitiveness within the new international economic order.

But the professionalised ALLN practitioner is a fantasy suffused by depthlessness and transparency. They are an anaesthetised, hollowed-out spectacle (Ball 2003) prepared to draw on inner resources for the corporate good: passionate about excellence, passionate about anything the corporation requires. They are prepared to teach not what students have struggled to articulate but that which has been predefined: dupe or devil (Bathmaker 2001) within a process that admits no other criteria for success.

The pervasiveness of professionalisation demands a response - but not one that has been pre-defined. One may choose to be absorbed (prepared to act superficially in a way that suggests acquiescence while maintaining a quietly subversive stance) - 'no one after all knows what's going on in my mind') or to be colonised (prepared to abandon any self-determined principles and become completely pre-defined by the corporation) by the new cultural ethos. Either way practitioners have no choice but to position themselves in relation to it. They are thus positioned by it. 
The above discussion suggests that from the perspective of the policy maker, professionalisation is wholly desirable. It hints that for ALLN learners and practitioners it may be less so. But what about an exploration of the inevitability of professionalisation? The new framework impacts upon the role of ALLN practitioners in profound ways. But the professionalisation invoked by policy makers is not an inevitable construct. To award it the status of predefined and unstoppable, is to award it the status of natural phenomenon, like the flow of a river. Inevitability it suggests there is nothing to be gained from exploring the ways practitioners may influence professionalisation - as policy or as practice. If ALLN practitioners are to locate agency, it is necessary to imagine what is and what might not be inevitable about the professionalising process.

\section{The professionalisation of ALLN: is it inevitable?}

In this section I am more speculative. The prescribed professionalisation of Skills for Life is one of the discursive resources practitioners draw upon when deciding 'what and how to do'. But the only inevitability of policy prescription is its uneven implementation.

My concluding section draws on a small scale research project, Controlling the Imagination, into the different meanings embedded in the notion of quality when applied to the teaching and managing of Skills for Life. It offers a glimpse of the inevitability of professionalisation. I draw, through a series of semi structured interviews with 16 ALLN teachers and managers in 10 different organisations, on the voices of practitioners who teach and / or manage ALLN in the south of England. The approach is one based loosely on grounded theory, with transcribed interviews analysed with the help of Atlas ti.

Goodrham's (2005) research with LSS workers is unequivocal. When asked about the status of their occupation, research participants did not see their practice as a 'true' profession. Nor did they regard the status of LSS practitioners as having ever been professional. In part this non-professional status was attributed to the fragmented nature of the practitioners' role. This disassociation with professional status does not undermine the value placed on the important role practitioners play. In these shifting discourses 'working professionally may signify something different from being a professional' (Lather 1991 cited by Edwards 1997:157). The ALLN practitioners I interviewed' had no doubt about the intrinsic value of their role, as one participant expressed it,

We all assume an air of integrity about what we're doing because I think it's important [...]

ALLN, Program Manager (1) 
Despite years of radical redefinition, practitioners retained what is most often associated with motivations that predate Skills for Life. I asked participants what made them start working in the field of ALLN.

That's really easy. It was almost as soon as I left university, I wanted to be involved in community development work. I wanted to be involved in learning and be involved in work I felt that addressed issues of disadvantage, poverty, and under achievement for the adult population. Almost pretty much the first thing I did on leaving university was to start as a literacy volunteer [...], and loved it and thought, 'This is great!'

ALLN, Senior Manager (1)

Yes ... coming from an AEI background. Adult Education Institute background. [...] brought me into contact with an awful lot of people who [....] would [...] be described as being underrepresented in education, but also disadvantaged in basic skills. ALLN, Senior Manager (2)

It is not that these participants were unaware of the policy prescriptions regarding why ALLN mattered. At other points during our conversation they were able to recount an in-depth understanding of the economic imperative that lay behind Skills for Life policy. What I notice here is that they make no reference to policy definitions of why Skills for Life matters in its economic framing when talking about their own motivations. There is an inconsistency between policy imperative and practitioner motivation.

The data on how ALLN practitioners talk about what mattered to their practice gave rise to a framework that located a tension between what practitioners aspired to, and what was demanded of them. For example,

I think there are two elements of [my role]. In terms of what the college demands as the quality program. There's my role within that. And there's also my role providing what I consider to be good quality service to the students.

\section{ALLN, Program Manager (2)}

This statement suggests that while practitioners strive to meet the external professionalisation requirements placed upon them, the actual needs, desires and possibilities of learners may remain unmet. There was also tension between the prescriptions of professionalisation as an ambiguous abstraction in contrast to something that was embodied, the actual experiences of quality - sometimes at odds with publicly sanctioned policy or professionalisation discourses. These were shifting constructions and I made no attempt to locate fixed professional types or types of responses. 
The line of thought I want to pursue here is one that imagines a space between aspiration and embodiment, a space that was reminiscent of ALLN as a community-based campaign.

In riding the crest of the professionalising wave, ALLN practitioners commit themselves to implementing a policy not through any sense of allegiance to the policy itself but because of what the policy momentum enabled them to do. What it provided was an institutional resource to pursue ALLN practitioners' long-held commitments.

In the teams themselves, there's a real commitment to Skills for Life. [...] I think it's correct to say, to the learners within the Skills for Life area. The Skills for Life thing is incidental. It's the commitment to the learners.

ALLN, Senior Manager (2)

In some instances Skills for Life has enhanced to a significant extent what had been a marginalised and misunderstood activity,

For many years literacy, numeracy and ESOL was always the poor relation. And didn't get the funding, didn't get the priority in colleges, didn't get the support, didn't get the staffing. We had to make do with part-timers. All that stuff that went on years ago.

ALLN, Senior Manager (2)

With Skills for Life policy sponsorship, ALLN teachers and managers have struggled to position themselves in the mainstream activities of their organisation.

In an attempt to embody, to make real their aspirations of Skills for Life, ALLN practitioners hijack the momentum and resource attached to policy to achieve their own purposes. There are glimmering shards here of the anti-professionalisation that pre-dates Skills for Life. Policy merely creates a particular environment and resources that in some instances practitioners are able to mobilise to meet what they see as the needs and entitlements of their learners. This 'campaigning' ALLN practice makes aspirations real. This is one of many potential spaces for the nurturing of a 'professional imagination' (Power 2008); a space in which practitioners trace careful and expert steps between individualism and determinism.

It is a space that denies the inevitability for professionalisation. It opens a space for further exploration.

\section{Concluding remarks}

In this paper I have argued that the possibility of a professionalised ALLN practice may represent a road along which policy makers and practitioners may travel without ever reaching a final destination. This relates to some extent to the nature of literacy and professional learning as a 
thoroughly situated social practice, a shape shifting entity that refuses fixed form. It also relates to aspects of ALLN practitioner sensibilities that are at odds with the privileging and distancing implied by professional status.

Central to this argument is the policy defined and driven nature of professionalisation. Policy prescription creates an environment within which practitioners work and implicates them in fulfilling an economic imperative for literate learning citizens with flexible dispositions able to service a globalised economy. Professionalisation is desirable for some. It allows policy makers to closely monitor the micro world of practice. Through professionalisation, policy makers become part of the pedagogic encounter. For the practitioner, driven by a commitment of horizontality in relationships, to equity and social justice, it is less so.

Yet how policy makers imagine practice is other than how practitioners experience it. Once enacted, the process of implementing policy is a more actively mediated negotiation than a painting by numbers. The practitioner embodied policy is fractured, redefined and changed to suit the local ecology. Practitioners at times draw on the momentum provided by policy to make real their aspirations. It is possible to talk of implementing policy in terms reminiscent of ALLN as a campaign. It offers the opportunity to secure a mainstream place for ALLN learners. There is then no inevitability to a vertically controlled implementation. It is a policy driven process shaped by and filtered through the motivations and values of practitioners.

\section{References}

Albright, J and Luke, A (2008) Pierre Bourdieu and Literacy Education, Routledge, Taylor \& Francis, London.

Avis, J, Bathmaker, A-M , and Parsons, J (2002) Communities of Practice and the Construction of Learners in Post-compulsory Education and Training, Journal of Vocational Education and Training, vol 54, no 1 , pp 586-600.

Ball, SJ (2003) The Teacher's Soul and the Terrors of Performativity, Journal of Education Policy, vol 18, no 2, pp 215-28.

Barton, D (2007a) Literacy, Lives and Learning, Routledge, London.

Barton, D (2007b) Literacy: An introduction to the ecology of written language, 2nd edn, Blackwell, Malden, MA and Oxford.

Bathmaker, A-M (2001) Neither Dupes Nor Devils: Teachers' constructions of their changing role in further education', presented at 5th Annual Conference of the Learning and Skills Research Network, Robinson College, Cambridge.

Castleton, G (2001) The Role of Literacy in Peoples' Lives: A case study of its use amongst the homeless in Australia, in Crother, J, Hamilton, M 
and Tett, L, eds, Powerful Literacies, National Institute for Adult Continuing Education, Leicester, pp 56-68.

Clarke, J and Newman, J (2005) The Rise of the Citizen Consumer: Implications for public service professionals, Changing Teacher Roles, Identities and Professionalism, Seminar 5: What can be learnt from

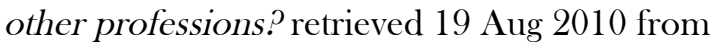
http://www.tlrp.org/themes/seminar/gewirtz/seminar5.html

Coffield, F and Edward, S (2009) Rolling out 'Good', 'Best' and 'Excellent' Practice. What next? Perfect practice?, British Educational Research Journal, vol 35, no 3, pp 371-90.

Coffield, F, Edward, S, Finlay, I, Hodgson, A, Spours, K and Steer, R (2008) Improving learning, skills and inclusion: the impact of policy on postcompulsory education, Routledge, Taylor \& Francis, London.

Crossan, B and Gallacher, J (2009) 'The boundaries are different out here': Learning relationships in community-based further education, in Edwards, R, Biesta, G and Thorpe, M eds, Rethinking contexts for learning and teaching: communities, activities and networks Routledge, Taylor \& Francis, London, pp133 - 46.

Crowther, J, Hamilton, M, and Tett, L (2001) Powerful Literacies, National Institute of Adult Continuing Education, Leicester.

Dennis, CA (2009) Controlling the Imagination: How do teachers and managers of adult language, literacy and numeracy define, achieve and maintain quality?, unpublished doctoral thesis, Department of Continuing and Professional Education; Institute of Education, University of London, London.

DfEE (1999) Improving Literacy and Numeracy : A fresh start : the report of the working group chaired by Sir Claus Moser, Department for Education and Employment, London.

Edwards, R (1997) Changing Places?: Flexibility lifelong learning and a learning society (London: Routledge) 214p.

Edwards , R (2003) Ordering Subjects: Actor-networks and the intellectual technologies in lifelong learning, Studies in the Education of Adults, vol 35, no 1, pp 54-67.

Edwards, R and Usher, R (2008) Globalisation \& Pedagogy: space, place and identity, 2nd edn, Routledge, Taylor \& Francis, London.

Elliott, G (1996) Educational Management and the Crisis of Reform in Further Education, Journal of Vocational Education \& Training, vol 48, no 1, pp 5-23.

Freire, P (1970) Cultural Action for Freedom, Harvard University Press, Cambridge, MA.

Frost, N (2001) Professionalism, Change and the Politics of Lifelong Learning, Studies in Continuing Education, vol 23, no 1, pp 5-17. 
Gleeson, D and James, D (2007) The Paradox of Professionalism in English Further Education: a TLC project perspective, Educational Review, vol 59, no 4, pp 451-67.

Goodrham, M (2005) Using Research to Enhance Professionaism in FE What kinds of professionalism are available to $\mathrm{FE}$ practitioners, paper presented at the 6th Annual Conference of the Teaching and Learning Research Programme, Warwick.

Haggis, T (2009) Beyond 'Mutual Constitution': Looking at learning and context from the perspective of complexity theory, in Edwards, Richard, Biesta, Gert and Thorpe, Mary, eds, Rethinking Contexts for Learning and Teaching: Communities, activities and networks, Routledge, Taylor \& Francis, London, pp 44-60.

Hamilton, M (2009) Putting Words in Their Mouths: The alignment of identities with system goals through the use of Individual Learning Plans, British Educational Research Journal, vol 35, no 2, pp 221-42.

Hamilton, M and Hillier, Y (2006) The Changing Face of Adult Literacy, Language and Numeracy 1970-2000: A critical history, Trentham Books, Stoke-on-Trent.

Harper, M and Jephcote, M (2010) Thematic Walkthrough in FE Literature on Professionalism and Professional Learning, Working Paper 11, Cardiff School of Social Sciences, University of Cardiff, Wales.

Hodgson, A and Spours, K (1999) New Labour's Educational Agenda: Issues and Policies for Education and Training from 14+, Kogan Page, London.

Hodgson, A, Edward, S and Gregson, M (2006) Riding the Waves of Policy in Adult and Community Learning in England: The case of basic skills, paper presented at the British Educational Research Association Annual Conference, University of Warwick, Warwick.

Ivanic, R, Appleby, Y, Hodge, R., Tusting, K and Barton, D 2006) Linking Learning and Everyday Life, National Research and Development Centre, London.

Jacobson, E (2009) Community Building as an Instructional Goal in Japanese Adult Basic Education, Adult Basic Education \& Literacy Journal, vol 3, no 3, pp 161-70.

James, D and Biesta, G (2007) Improving Learning Cultures in Further Education, Routledge Taylor \& Francis, London.

Jameson, J and Hillier, Y (2008) 'Nothing will prevent me from doing a good job'. The professionalisation of part-time teaching staff in further and adult education, Research in Post-Compulsory Education, vol 13, no 1, pp 39-53.

Kelchtermans, G (2007) Macropolitics Caught up in Micropolitics: The case of the policy on quality control in Flanders (Belgium), Journal of Education Policy, vol 22, no 4, pp 471-91. 
Leitch, S (2006) Prosperity for All in the Global Economy: World class skills: executive summary, Department for Education and Employment, London.

LLUK (2010), Lifelong Learning UK - Research and Workforce Data Collection, retrieved 19 Aug 2010 from http://www.lluk.org/3146.htm

Morley, L (2003) Quality and Power in Higher Education, Open University Press, Berkshire.

Payne, J (2000) The Unbearable Lightness of Skill: The changing meaning of skill in UK policy discourses and some implications for education and training', Journal of Education Policy, vol 15, no 3, pp 353-69.

Peters, T and Austin, A (1985) A Passion for Excellence, Fontana/Collins, Glasgow.

Power, S (2008) The Imaginative Professional, in Cunnigham, B, ed, Exploring Professionalism, Bedford Way Papers, Institute of Education, pp1 44-60.

Randle, K and Brady, N (1997) Managerialism and Professionalism in the 'Cinderella Service', Journal of Vocational Education \& Training, vol 49, no 1, pp 121-39.

Robson, J (1998) A Profession in Crisis: Status, culture and identity in the further education college, Journal of Vocational Education \& Training, vol 50, no 4, pp 585-607.

Sardar, Z (2000) Professionals Who Lost their Virtue, New Statesman, retrieved 9 Aug 2010 from http://www.newstatesman.com/200007100019

Shain, F (1999) Changing Notions of Teacher Professionalism in the Further Education Sector, paper presented at the British Educational Research Association Annual Conference, Queen's University of Belfast, Northern Ireland.

Shore, S and Zannettino, L (2002) Professional Development in Australian Adult Literacy and Numeracy Provision, in Shore, S ed, Lessons from the Past, Insights for the Future: what do we know about literacy and numeracy provision? ALNARC, South Australia.

Stronach, I (2002) Towards an Uncertain Politics of Professionalism: Teacher and nurse identities in flux, Journal of Education Policy, vol 17, no 1 , p 109.

Tusting, K (2009) 'I am not a "good" teacher; I don't do all their paperwork': Teacher resistance to accountability demands in the English Skills for Life strategy', Literacy \& Numeracy Studies, vol 17, no 3, pp 6-26.

Wickert, R (2001) Politics, Activism and Processes of Policy Production: Adult literacy in Australia, in Lo Bianco, J and Wickert, R eds, Australian policy activism in language and literacy, Language Australia, Melbourne, pp 75-91. 
Wilson, AL (2001) Professionalization: A politics of identity, New Directions for Adult \& Continuing Education, vol 2001, no 91, pp 73-84.

${ }^{1}$ Pen portraits of research participants who were involved with 'Controlling the Imagination'.

Pen Portraits of Project Participants quoted in this paper

\begin{tabular}{l|l} 
ALLN, & has worked in adult education as an ESOL specialist for some years. Her role
\end{tabular} \begin{tabular}{l|l} 
Program & includes a considerable amount of teaching and supporting other teachers.
\end{tabular}

Manager (1) Although based in an FE college she is also responsible for off-site community provision. Employed as a manager with some teaching, she saw herself firstly as a teacher and placed great emphasis on the importance of this throughout our conversation. She narrates an organisational biography that equated quality with nothing more than hard work. She views ALLN provision as peripheral in a college that would rather be doing other more glamorous subjects.

ALLN, Senior is a long standing ALLN professional. Her role no longer had a direct ALLN

Manager (1) focus and our conversation came about primarily because of her past connection. I have had an extended day-to-day working relationship with this participant. She has a 'holding brief' for ALLN rather then direct line management responsibility. She had worked in the organisation for a number of years and at times had been a manager and teacher of ALLN in the college. The college has a very high profile reputation for quality in the area of work and has maintained a grade two for some time. There is a strong narrative through the college of it having changed from a failing organisation to one with a national profile.

\begin{tabular}{l|l} 
ALLN, & as a senior manager her role did not include teaching. She is a long time
\end{tabular} Senior Manager veteran of Skills for Life and has retained much of the evangelical zeal that (2) led her to this area of work. At the time of the interview she was just about to be promoted to a more senior management position. The department has had a varied recent past. Having sustained a grade two for a number of years and a self-referenced reputation for quality and innovative provision, it expanded exponentially in a very short period of time and in the inspection before last was graded as unsatisfactory. She has worked for the college throughout this time and her role has changed in relation to ALLN, from a direct curricular to overall strategic responsibility.

\begin{tabular}{l|l} 
ALLN, & had a role that included both teaching and managing, two joined fractional
\end{tabular} \begin{tabular}{l|l} 
Program & posts to make up a single full-time role. Based in a further education college
\end{tabular} Manager (2) in London she has an English as a Foreign Language (EFL) background and had taught overseas for some years. The experience of working in the private sector and the entrepreneurial flair that came with it is something she carries with her into her current role. She arrived back in England at the start of the Skills for Life policy and has little recollection of a pre-Skills for Life FE sector. 